\title{
Combined Application of $17 \beta$-Estradiol and Progesterone Enhance Vascular Endothelial Growth Factor and Surfactant Protein Expression in Cultured Embryonic Lung Cells of Mice
}

\author{
Andreas Trotter, ${ }^{1}$ Markus Kipp, ${ }^{2}$ Roland Matthias Schrader, ${ }^{2}$ and Cordian Beyer ${ }^{2}$ \\ ${ }^{1}$ Section of Neonatology, Center for Perinatal Medicine, Children's Hospital, University of Bonn, 53105 Bonn, Germany \\ ${ }^{2}$ Institute of Neuroanatomy, RWTH Aachen University, 52057 Aachen, Germany \\ Correspondence should be addressed to Andreas Trotter, andreas.trotter@web.de
}

Received 16 November 2008; Accepted 17 February 2009

Recommended by Dharmapuri Vidyasagar

Preterm delivery is associated with disruption of the placental supply with $17 \beta$-estradiol (E2) and progesterone (P). The aim is to evaluate the role of $\mathrm{E} 2$ and $\mathrm{P}$ on the regulation of key proteins in lung development in embryonic lung cells. Alveolar cell type II (AT-II) and central lung fibroblast cultures were established from mouse embryos. Cells were exposed for 24 hours to E2 and/or P, the estrogen receptor antagonist ICI 182,780 (ICI) and the progesterone receptor antagonist mifepristone (RU 486). The mRNA expression of vascular endothelial growth factor (VEGF) and surfactant protein B and C (SB-B, SB-C) was determined and protein levels of VEGF were measured. Only the combined treatment with E2 and P increased mRNA expression and VEGF protein in AT-II cells and lung fibroblasts. Combined treatment also promoted SP-B and SP-C expression in AT-II cells. Pretreatment with ICI and RU 486 completely abolished the E2 and P induced effects. E2 and P enhanced expression of VEGF and surfactant proteins in primary embryonic lung cells and may be involved in regulating expression of key molecules for the prenatal lung development and postnatal lung function.

Copyright (C) 2009 Andreas Trotter et al. This is an open access article distributed under the Creative Commons Attribution License, which permits unrestricted use, distribution, and reproduction in any medium, provided the original work is properly cited.

\section{Introduction}

Respiratory distress syndrome (RDS) and bronchopulmonary dysplasia (BPD) remain major factors for morbidity and mortality in extremely preterm infants. Histopathological studies in preterm infants dying from BPD demonstrate an arrest of lung development with reduced alveologenesis [1]. The concept has evolved that postnatal lung development in extremely preterm infants is arrested by lack of factors that regulate lung differentiation and maturation in utero [2]. During mid and late gestation, the human fetus is exposed to high amounts of $17 \beta$-estradiol (E2) and progesterone $(\mathrm{P})$ [3] produced by the placenta from precursors originating from the mother and the fetus [4]. Delivery disrupts the placental supply of both hormones. Within one day, the levels of E2 and P drop 100-fold [5]. This is a physiologic condition for the term infant. The extremely preterm infant is disrupted from the supply of these hormones at a much earlier developmental stage. The uterus as a known estrogen responsive target grows in utero until the end of gestation but stops growing in preterm infants [6]. It is conceivable that the withdrawal of E2 and $\mathrm{P}$ at this early developmental stage also affects lung development. Replacement of E2 and P in extremely preterm infants tailored to maintain in utero plasma levels of E2 and $\mathrm{P}$ was associated with a trend toward a reduced incidence of $\operatorname{BPD}[5,7]$.

In mice lung mRNA expression of estrogen and progesterone receptors suggests that $\mathrm{E} 2$ and $\mathrm{P}$ are likely to be involved in mammalian fetal lung development [8]. The number of alveolar crests and alveolar type II cells [9] as well as lamellar bodies in type II cells [10] increased in rat fetuses after maternal E2 administration and E2 stimulates fetal lung surfactant production in rabbits $[11,12]$. In newborn piglets antagonism of E2 and $\mathrm{P}$ during mid to late pregnancy decreased alveolarization [13]. 
Vascular endothelial growth factor (VEGF) is a major mitogen for vasculogenesis and angiogenesis [14] and is essential for embryonic development. Loss of a single VEGF allele results in embryonic lethality [15]. Absence of isoforms of VEGF impairs lung microvascular development and delays airspace maturation in mice fetuses reflecting the essential role of VEGF for normal lung development [16]. Pneumotrophic effects may be mediated through modulation of VEGF expression with the potential to accelerate lung maturation in preterm infants [17]. Intra-amniotic injection of VEGF in preterm rats resulted in increased surfactant protein B (SP-B) mRNA expression [18]. Type 2 pneumocytes respond to VEGF by increasing their expression of SP-B and SP-C [17].

Both sex steroids E2 and P and VEGF are described to induce surfactant proteins in the developing lung. Whereas it is established that E2 and P induce VEGF gene transcription in breast tumor cell lines [19] and the endometrium [20-22] no data from the literature is available about the effects of E2 and $\mathrm{P}$ on VEGF gene transcription in lung tissue. The aim of this study was to investigate if $\mathrm{E} 2$ and $\mathrm{P}$ are involved in the developmental regulation of VEGF and surfactant protein $B$ (SB-B) and C (SB-C) mRNA expression using an in vitro model of cultured embryonic lung cells.

\section{Material and Methods}

All experiments followed the local guidelines according to the Federation of European Laboratory Animal Science Associations recommendations and were approved by local executives.

2.1. Cell Culturing and Treatment. Highly enriched alveolar cell type II (AT-II) and central lung fibroblast cultures were established from embryonic day (ED) $18 \mathrm{BALB} / \mathrm{c}$ mice as followed. Since E18 mouse lungs can be dissected from the surrounding vessels in a reliable manner we did choose this developmental stage to isolate purified AT-II cells from the mouse lung. Briefly, the fetuses were removed on ED 18 by caesarian section and the lungs aseptically explanted from the thorax. Lungs were then washed three times in $10 \mathrm{~mL}$ ice cold HBSS, mechanically dissected from surrounding vessels, and then incubated in a $2.5 \%$ trypsin solution containing $200 \mu \mathrm{L}$ of DNAse 1 ( $2 \mathrm{mg} / \mathrm{mL}$, Worthington) for 10 minutes at $37^{\circ} \mathrm{C}$ in a shaking water bath $(60 \mathrm{rpm})$. Finally, the cell suspension was filtered through a nylon mesh with $100-\mu \mathrm{m}$ pore size. The cell suspension was centrifuged twice at 420 and then $120 \mathrm{~g}$ for 4 minutes, and the pellet was resuspended in minimal essential medium (MEM). The resulting cell suspension contained the AT-II cells and attaching fibroblasts. After adding 1.5 ML collagenase (1250 U/mL, Worthington) and $150 \mu \mathrm{L}$ DNAse $1(2 \mathrm{mg} / \mathrm{mL}$, Worthington) the suspension was incubated for 15 minutes at $37^{\circ} \mathrm{C}$. After stopping the collagenase activity by incubating in ice-cold MEM (supplemented with 10\% FCS) the cell suspension was centrifuged as above for 4 minutes and the pellet was resuspended in MEM $+10 \%$ FCS. Cells were seeded and cultivated in a fibronectin-coated culture flask for 1 hour at $37^{\circ} \mathrm{C}$ under $5 \% \mathrm{CO}_{2} / 21 \% \mathrm{O}_{2}$. During this time, fibroblasts were attached to the flask, while AT-II cells did not due to their differential adherence characteristics. This procedure was repeated twice. Finally, approximately $1 \times 10^{5}$ AT-II cells $/ \mathrm{cm}^{2}$ were seeded at 24 -well culture plates, cultured for one day in MEM supplemented with 10\% FCS. Medium was changed after 24 hours to Cellgro complete medium (Mediatech, Virginia, USA, without phenol red). Attached fibroblasts were resuspended by trypsination and replated. When cells reached a confluence of approximately $80 \%$ the medium was changed and the final treatment was started. Cells were exposed for 24 hours to E2 and/or P and dexamethasone (all from Sigma-Aldrich, Germany) in concentrations ranging from $10-10 \mathrm{M}$ to $10-6 \mathrm{M}$. Pretreatment with the estrogen receptor antagonist ICI 182,780 (TOCRIS bioscience, UK, $0.1 \mu \mathrm{M}$ ) and the progesterone receptor antagonist mifepristone (RU 486 from Biomol, Germany, $0.1 \mu \mathrm{M}$ ) was performed 1 hour before hormone exposure. Concentrations of ICI and RU 468 were derived by preparing a $10-2 \mathrm{M}$ stock solution in ethanol $100 \%$ p.a. quality and by further diluting in medium. Appropriate ethanol concentrations served as controls.

2.2. Gene Expression Analysis. The mRNA expression of VEGF, SP-B, and SP-C was quantified using the rtPCR technology (BioRad, Germany), QTM SYBR Green Supermix (BioRad, Germany), and a standardized protocol as described previously $[23,24]$. Isolation of total RNA was performed with peq Gold (PeqLab, Germany). RNA concentration and purity were assessed using OD260 and OD260/OD280 ratio, respectively, and reverse transcribed using an Invitrogen M-MLV RT-kit and random hexanucleotide primers. The rtPCR reactions were carried out in a reaction mixture consisting of $2 \mu \mathrm{L}$ cDNA, $6 \mu \mathrm{L}$ RNAsefree water, $10 \mu \mathrm{L}$ hot StartTaq DNA-polymerase, and $1 \mu \mathrm{L}$ of primer $(10 \mathrm{pmol})$. Reactions were conducted in standard tubes using the MyIQ rtPCR Detection System (BioRad, Germany) under following conditions: 10-minute enzyme activation at $95^{\circ} \mathrm{C}, 45$ cycles of 15 -second denaturation at $95^{\circ} \mathrm{C}, 30$-second annealing at individual temperatures, 30second amplification at $72^{\circ} \mathrm{C}$, and 5-second fluorescence measurement at $80^{\circ} \mathrm{C}$. Primer sequences to detect VEGF, SP$\mathrm{B}$, and SP-C are shown in Table 1. Relative quantification was performed using the $\Delta C t$ method, which results in ratios between target genes and a housekeeping reference gene (HPRT). As the validity of this method critically depends on the constant expression of the housekeeping gene, constant expression of HPRT was tested against other housekeeping genes (not shown). In each run, external standard curves were generated by several fold dilutions of target genes. The concentration of the target genes was calculated by comparing $C t$ values in each sample with $C t$ values of the internal standard curve. Finally, data were expressed as the ratio of the amount of each transcript versus the concentration of HPRT. Melting curves and gel electrophoresis of the PCR products were routinely performed to determine the specificity of the PCR reaction.

2.3. Protein Analysis. An ELISA for VEGF was conducted according to the manufacturer's instructions (RayBiotech 
TABle 1: Primer sequences for mRNA detection of the different gene products.

\begin{tabular}{|c|c|c|c|c|}
\hline Gen & Forward & Reverse & bp & AT \\
\hline VEGF* & cca cgt cag aga gca aca tca & tca ttc tct cta tgt gct ggc ttt & 71 & 60 \\
\hline SP-B & cca cct cct cac aaa gat gac & ttg ggg tta atc tgg ctc tgg & 174 & 60 \\
\hline SP-C & atg gac atg agt agc aaa gag gt & cac gat gag aag gcg ttt gag & 119 & 60 \\
\hline ER-a & cgt gtg caa tga cta tgc ctc & ttt cat cat gcc cacttcgtaa & 199 & 62 \\
\hline ER-b & ctg tga tga act acagtg ttc cc & gca gtg ggt ggc taa agg a & 124 & 62 \\
\hline PR & cca act tca caa aac ttc tcg aca & ggc agc aat aac ttc aga cat ca & 127 & 64 \\
\hline HPRT & gct ggt gaa aaggac ctc $t$ & cac agg act aga aca cct gc & 248 & 62 \\
\hline
\end{tabular}

* recognizes transcript variants VEGF 120, 144, and 164.

ELISA Kit, specific for VEGF-A). For each sample, blank values (i.e., those for serum-free media) were subtracted, and mean results were normalized per $10^{5}$ cells, counted after trypsination in a Neubauer's counting chamber. This assay was performed in triplicate experiments.

2.4. Immunostaining. Purity of cell cultures was determined by immunohistochemistry for vimentin (fibroblasts, abcam, Germany, 1:100) and cytokeratin (AT-II cells, abcam, Germany, 1:75). Cells were grown on top of autoclaved $13 \mathrm{~mm}$ circular glass cover slips placed in each well of a 24-well plate. After incubation, the media were aspirated, and cells were washed twice in PBS. Cells were fixed in methanol and incubated with 1\% BSA and 2\% FCS in PBS for 20 minutes at $23^{\circ} \mathrm{C}$ prior to exposure to primary antibodies for 18 hours at $4^{\circ} \mathrm{C}$. Appropriate secondary antibodies and the AEC Kit (Zymed Laboratories, Calif, USA) were used for staining.

2.5. Statistical Analysis. Differences between groups were tested by one-way analysis of variance (ANOVA) followed by Tukey's post hoc multiple range test using SPSS software (SPSS Inc., Chicago, IL, USA). A $P$-value of less than .05 was considered significant. Results in figures are presented as means with standard error of the mean.

\section{Results}

3.1. Cell Culture Purity and Receptor Expression. The culturing protocol for lung fibroblast yielded a greater than $98 \%$ homogeneity of vimentin-positive fibroblasts. The culturing protocol for AT-II cells yielded a greater than 95\% homogeneity of cytokeratin-positive cells. Cross contamination of purified fibroblasts cell cultures was excluded by immunohistochemical staining of fibroblast cell cultures with anticytokeratin antibody (Figure 1). No expression of SP-B and SP-C was detected in lung fibroblasts further proving purity of cell cultures. Semiquantitative PCR revealed that all three hormone receptors, namely, estrogen receptor alpha (ER- $\alpha)$, estrogen receptor beta (ER- $\beta$ ), and the progesterone receptor (PR) are expressed in purified central lung fibroblast and ATII cell cultures (Figure 2).

3.2. Hormonal Effects on Central Lung Fibroblasts. The treatment of cultured fibroblast with either E2-8 M or P$8 \mathrm{M}$ alone for 48 hours had no significant influence on VEGF mRNA expression (Figure 3). However, a combined

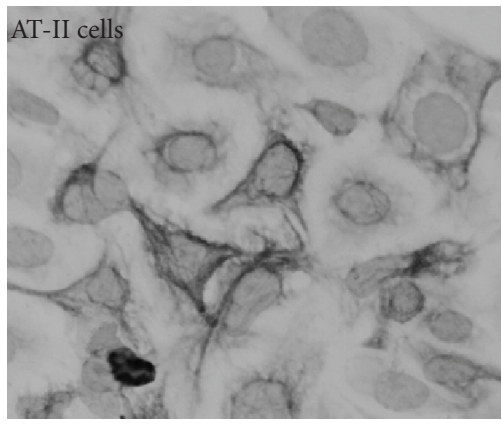

(a)

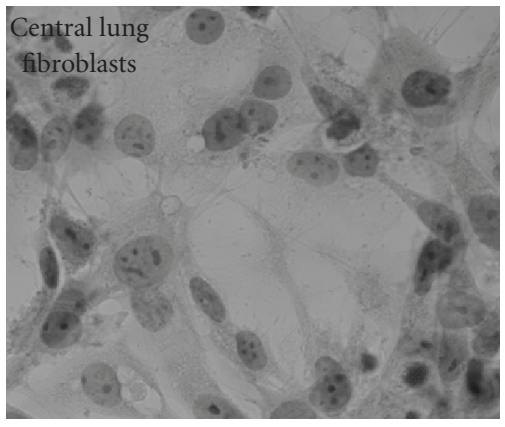

(b)

FIgURE 1: Alevolar cells type II (AT-II) and central lung fibroblasts stained with cytokeratin antibody. Note that AT-II stain positive for cytokeratin whereas fibroblasts do not. Therefore, contamination of AT-II cells in fibroblast cell cultures can be excluded.

application with both steroids resulted in a significant increase by approximately $100 \%$ compared to controls in VEGF mRNA levels $(P<.01$, Figure 3$)$. Dexamethasone was applied as positive control $(P<.01$, Figure 3$)$. The combined application at concentrations lower than 10-8 $\mathrm{M}$ did not significantly affect VEGF mRNA expression (Figure 4), and higher concentrations (10-6 M) did not further promote VEGF mRNA expression compared to 10-8 M (Figure 4). The hormone-induced upregulation of VEGF mRNA was completely blocked by the application of the receptor antagonists ICI and RU 486 (Figure 4). The single or combined treatment with ICI and/or RU 486 did not influence the basal expression of investigated proteins as determined by rt-PCR analysis (data not shown). Using ELISA analysis, we could 


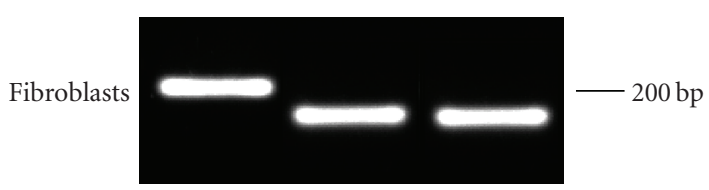

(a)

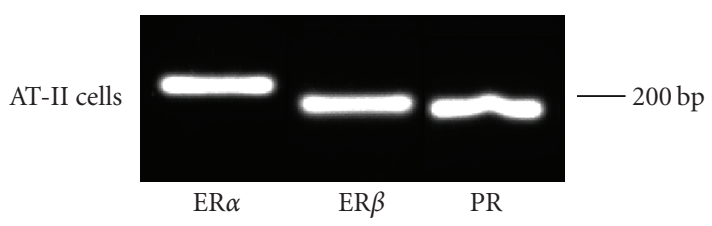

(b)

FIGURE 2: Semiquantitative analysis of estrogen receptor alpha (ER$\alpha$ ), estrogen receptor beta $(\mathrm{ER}-\beta)$, and the progesterone receptor (PR) expression in central lung fibroblast and AT-II cell cultures. Note that all three hormone receptors are expressed in both cell cultures.

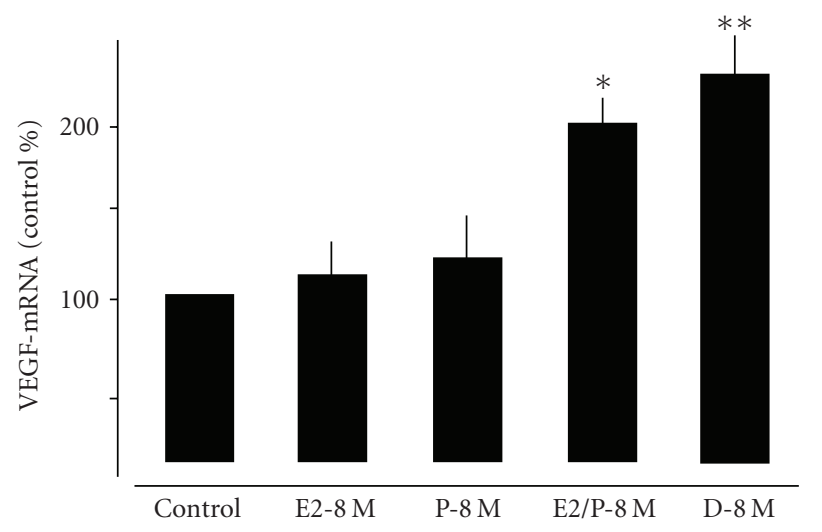

FIGURE 3: Quantitative analysis of VEGF gene expression in central lung fibroblasts treated for 48 hours with E2-8 M and P-8 $\mathrm{M}$ alone or in combination. Values were normalized against a housekeeping gene (HPRT) and expressed as \% of controls. Note that only the combined application of both hormones significantly increased VEGF expression in central lung fibroblasts. Also note that the application of dexamethasone (D) had similar effects on VEGF expression. ${ }^{*} P<.01$ control versus $\mathrm{E} 2 / \mathrm{P}-8 \mathrm{M},{ }^{* *} P<.01$ control versus D-8 M.

confirm the transcriptional regulation of VEGF by E2 and P. Only the combined application increased extracellular VEGF protein levels in fibroblasts (Figure 5). Pretreatment with the receptor antagonists again abrogated this effect.

3.3. Hormonal Effects on AT-II cells. As shown for fibroblasts only the simultaneous exposure to E2-8 M and P-8M significantly enhanced the expression of VEGF (Figure 6) and this could be confirmed at the transcriptional level (Figure 7). Dexamethasone also increased VEGF amount in AT-II cells (Figure 6). Combined application of E2 and P increased mRNA expression of SP-B and SP-C to a similar extent as dexamethasone (Figure 8). Pretreatment with the receptor antagonists ICI and RU 468 abrogated this effect. SP-A was not found in AT-II cells, however was expressed in

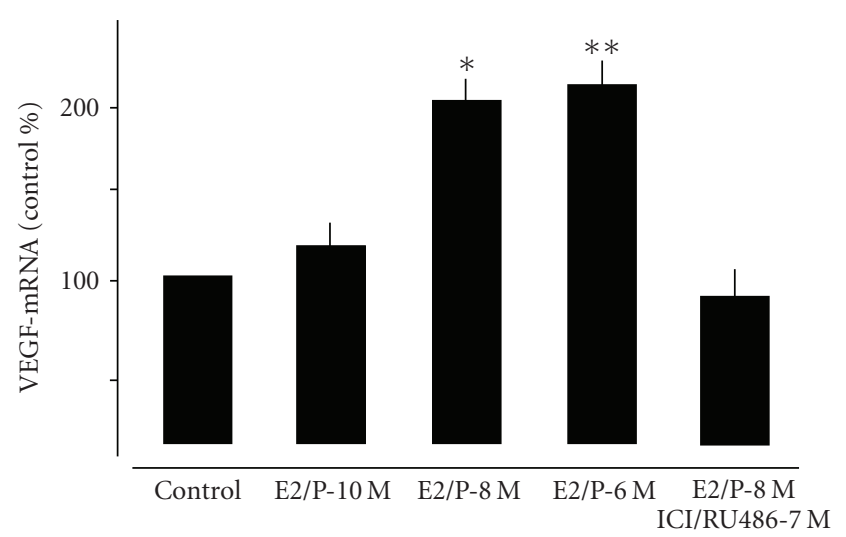

FIGURE 4: Quantitative analysis of VEGF gene expression in central lung fibroblasts treated for 48 hours with increasing concentrations of both E2 and P and with ICI/RU 486. Values were normalized against a housekeeping gene (HPRT) and expressed as \% of controls. Note that the application of receptor antagonists 1 hour prior to hormone application (ICI/RU 486) antagonizes hormonal effects. $P<.01$ control versus $\mathrm{E} 2 / \mathrm{P}-8 \mathrm{M}$; ${ }^{* *} P<.01$ control versus E/P-6 M.

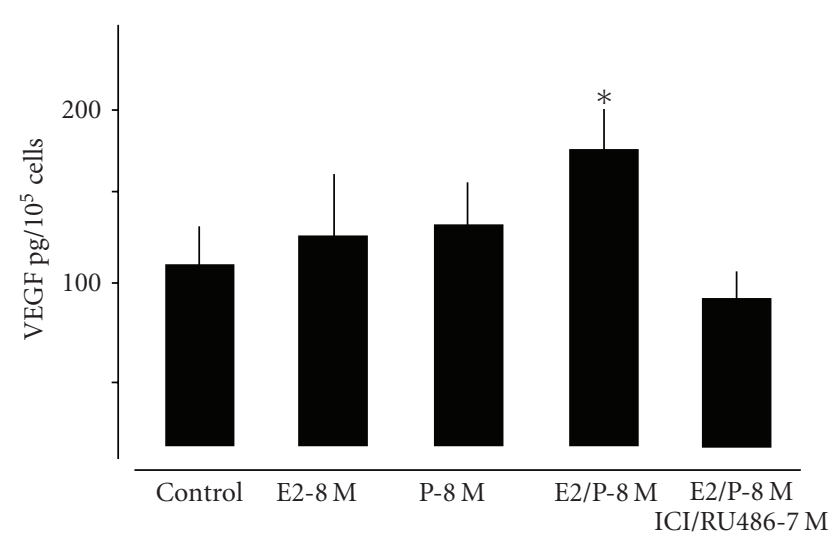

FIGURE 5: Quantification of VEGF protein release of lung fibroblasts treated for 48 hours with E2-8 M and P-8 M alone or in combination determined by ELISA. Note that corresponding with results obtained by gene expression analysis (Figure 3) VEGF protein is increased in central lung fibroblast cultures only by combined treatment with E2 and P. Pretreatment with ICI/RU 486 abrogated this effect. ${ }^{*} P<.05$ control versus $\mathrm{E} 2 / \mathrm{P}-8 \mathrm{M}$.

mature lung tissue which did serve as a positive control (not shown).

\section{Discussion}

The role of angiogenic growth factors for developmental processes is increasingly recognized [25]. A decreased expression may be a potential mechanism of alveolar capillary dysmorphogenesis in BPD. In animal models of bronchopulmonary dysplasia and in preterm infants dying from BPD, diminished VEGF mRNA expression is evident (for a review see [25]). VEGF stimulates the growth of lung epithelial cells in vitro [26] and is important for pulmonary vascular development [27]. Mice with a deficiency of VEGF die 


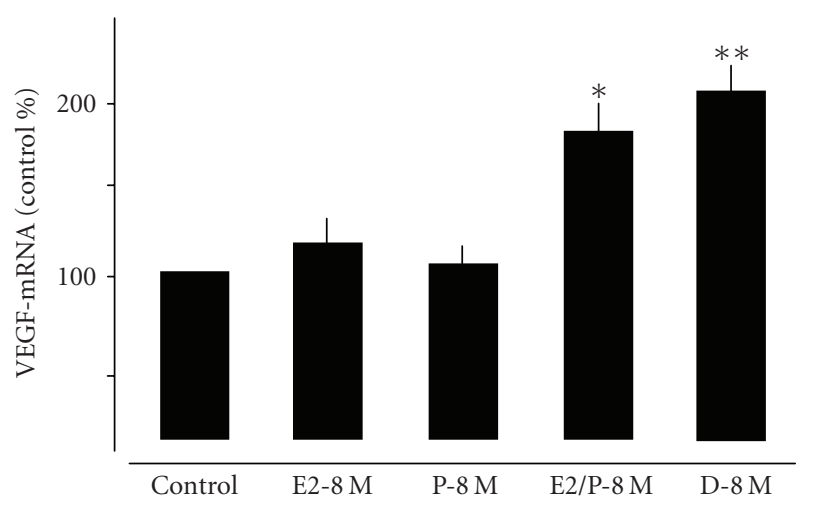

FIGURE 6: Quantitative analysis of VEGF gene expression in alveolar cells type II treated for 48 hours with E2-8 M and P$8 \mathrm{M}$ alone or in combination. Values were normalized against a housekeeping gene (HPRT) and expressed as \% of controls. Note that only the combined application of both hormones significantly increased VEGF expression in central lung fibroblasts. Also note that the application on dexamethasone had similar effects on VEGF expression. ${ }^{*} P<.01$ control versus $\mathrm{E} 2 / \mathrm{P}-8 \mathrm{M}$, ${ }^{* *} P<.01$ control versus $\mathrm{D}-8 \mathrm{M}$.

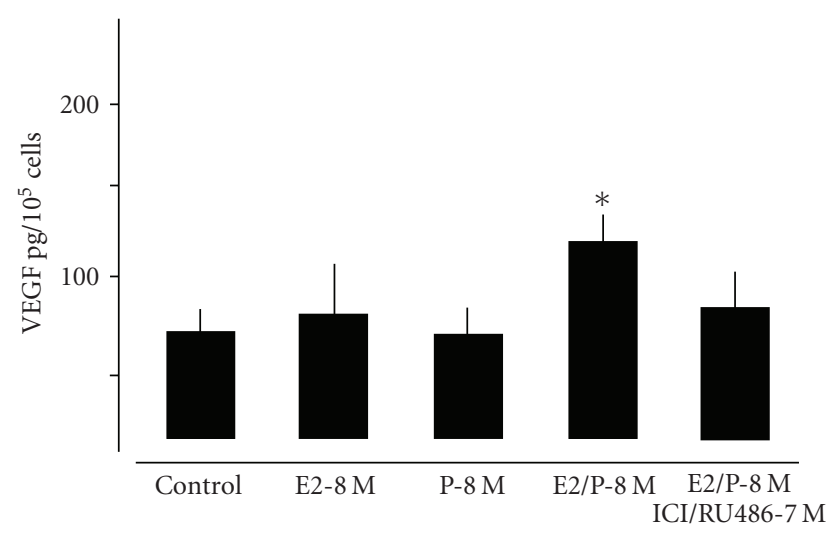

FIGURE 7: Quantification of VEGF protein release of alveolar cells type II treated for $48 \mathrm{~h}$ with E2-8 M and P-8 M alone or in combination determined by ELISA. Note that corresponding with results obtained by gene expression analysis (Figure 6) VEGF protein is increased in alveolar type II cell cultures only by combined treatment with E2 and P. Pretreatment with ICI/RU 486 abrogated this effect. ${ }^{*} P<.05$ control versus E2/P- $8 \mathrm{M}$.

from RDS [17], and VEGF knockout results in embryonic lethality [15]. To our knowledge no data on the influence of $\mathrm{E} 2$ and $\mathrm{P}$ on VEGF expression in the developing lung is available. In primary lung fibroblasts and AT-II cells only the combined application of $\mathrm{E} 2$ and $\mathrm{P}$ resulted in increased expression levels of VEGF mRNA and VEGF protein. This effect was abolished by pretreatment with the specific E2 and $\mathrm{P}$ antagonists ICI and RU 486, respectively. Assuming that $\mathrm{E} 2$ and $\mathrm{P}$ increase VEGF expression in the developing lung in vivo, the withdrawal of the placental supply of $\mathrm{E} 2$ and $\mathrm{P}$ in preterm infants may explain the disturbed lung development and function. Postnatal replacement of E2 and P in preterm

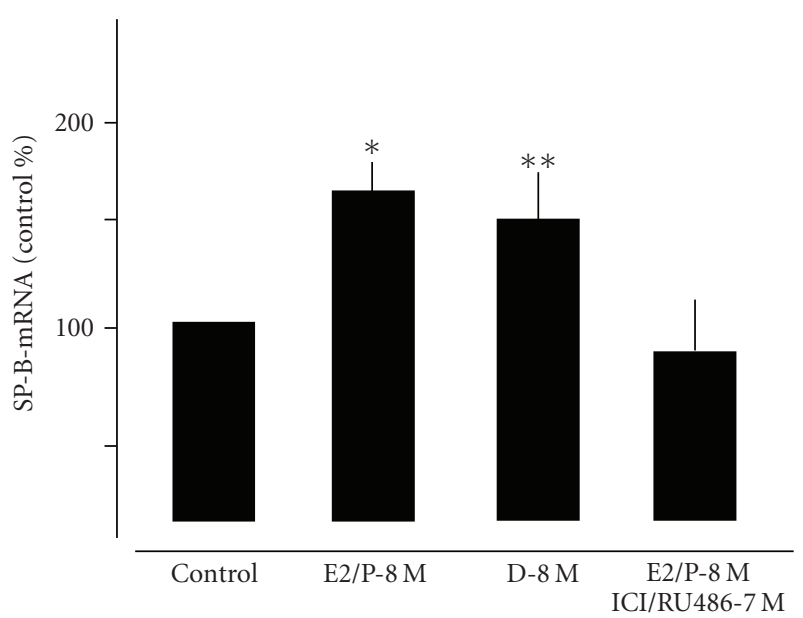

(a)

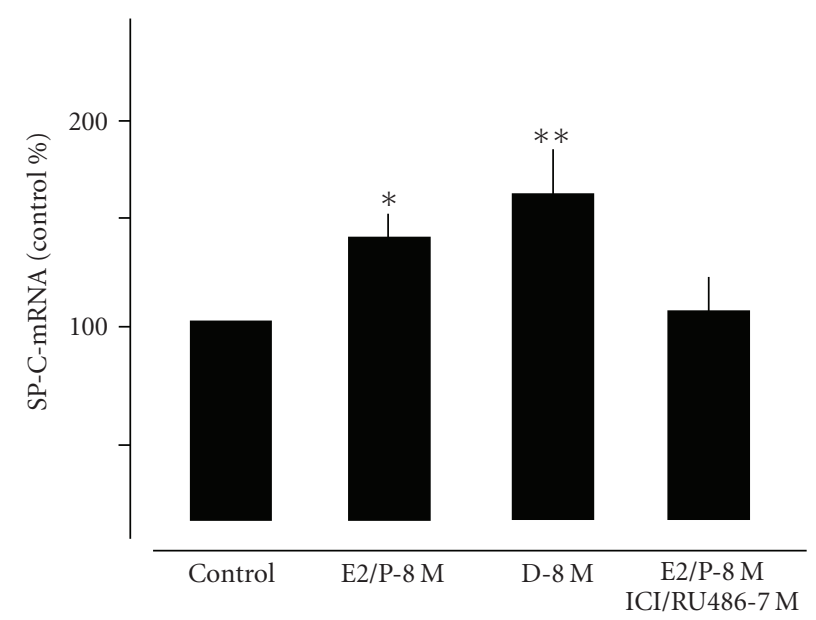

(b)

FIGURE 8: Quantitative analysis of SP-B and SP-C gene expression in alveolar cells type II treated for 48 hours with E2-8 M/P$8 \mathrm{M}$ in combination or with dexamethasone- $8 \mathrm{M}$. Values were normalized against a housekeeping gene (HPRT) and expressed as $\%$ of controls. Note that combined hormonal treatment increased expression of both surfactant proteins to a similar extent like dexamethasone. Further note that pretreatment with the receptor antagonists ICI and RU 486 antagonized the hormonal effects. ${ }^{*} P<$ .01 control versus E2/P-8 M; ${ }^{* *} P<.01$ control versus D-8 M.

infants was associated with a trend toward reduced incidence of BPD $[5,7]$.

Disturbed lung function in RDS of preterm infants is due to surfactant deficiency. A regulative role of E2 in surfactant synthesis is supported by enhanced mRNA expression for SPB found in fetal rabbit lung cells [28]. Our data supports a regulative role of E2 and P for surfactant synthesis as in AT-II cells combined treatment with E2 and P resulted not only in increased VEGF but also in increased mRNA expression of SP-B and SP-C. We did not perform experiments to evaluate the role of VEGF for surfactant synthesis. However, data from the literature implicates a trigger function of VEGF for surfactant synthesis. Intra-amniotic injection of VEGF in preterm rats resulted in increased SP-B mRNA expression 
[18]. Furthermore, type II pneumocytes respond to VEGF by enhancing their expression of SP-B and SP-C [17]. We speculate that $\mathrm{E} 2$ and $\mathrm{P}$ promote VEGF production and, thereby, surfactant synthesis.

One major finding of our study is that only the combination of $\mathrm{E} 2$ and $\mathrm{P}$ was effective in the upregulation of VEGF, SP-B, and SP-C expression. This is in accordance with findings about the epithelial $\mathrm{Na}^{+}$-channel which plays a critical role in the active reabsorption of alveolar fluid at the time of birth and during pulmonary oedema. In rats, only the combined application of E2 and P promoted mRNA levels of the epithelial $\mathrm{Na}^{+}$-channel in the lung suggesting complex interactions between the intracellular E2 and P signalling [29]. It appeared that only the administration of both hormones is fully effective in preventing demyelination in a multiple sclerosis animal model [30]. It is well known that ER and PR are coexpressed in the same cells in several areas of the target tissues [31, 32]. In addition, a number of reports demonstrated that ER and PR can have synergistic or inhibitory cross-talk in their transcriptional regulation in promoter type- and PR subtype-specific manners [33, 34]. Also interactions on well-known nongenomic levels are assumed. For example, in breast cancer cells, estrogens activate the Src/Erk pathway through an interaction of the ER with the SH2 domain of c-Src. Progestins have been reported to activate also this pathway either via an interaction of the PR with ER, which itself activates c$\mathrm{Src}$, or by direct interaction of PR with the $\mathrm{SH} 3$ domain of c-Src [35]. Future studies have to show the underlying mechanisms for combined positive hormonal effects. The preterm infant is deprived of both $\mathrm{E} 2$ and $\mathrm{P}$, simultaneously. Our study adds evidence that only combined replacement of E2 and P may be effective to prevent BPD in preterm infants $[5,7]$.

Treatment with dexamethasone increased VEGF mRNA expression and VEGF protein in lung fibroblasts and ATII cells. In contrast, in vitro studies have shown that dexamethasone downregulates VEGF expression in cells derived from alveolar epithelial cells [36]. However, in mid-trimester fetal human lung explants dexamethasone increased VEGF mRNA expression [37] and this at least at the translational level was also found in vivo [38]. Interestingly, treatment of preterm infants with dexamethasone was associated with increased VEGF levels in deep pulmonary lavages [39].

The embryos were not stratified by gender. Therefore, we cannot exclude that by chance some experiments were conducted in cell cultures from predominant male or female embryos. The steroid concentrations being most effective in our experiments, that is, 10-8 M, appear at first glance to be above the physiological plasma levels found in rodents during the estrous cycle. However, it is generally accepted that under in vitro conditions higher steroid levels are required to yield cellular effects. In previous in vitro studies, these high estrogen concentrations were applied to generate physiological effects $[40,41]$. Another more intriguing point is that tissues themselves produce steroids. Thus, tissue intrinsically synthesized steroids may contribute together with plasma steroids to reach higher local tissue steroid concentrations. In support for this view is the recent observation that in rodent hippocampal tissue local estrogen production yields tissue steroid levels at approximately $10-9 \mathrm{M}$ which are greater than those in the plasma [42].

In conclusion, combined use of E2 and $\mathrm{P}$ enhanced expression of VEGF and surfactant proteins in primary embryonic lung cells. These proteins are known to be key factors for the prenatal lung development and postnatal lung function. Further research about the effects of E2 and P on lung development may open therapeutic perspectives for preterm infant prone to develop lung disease.

\section{Abbreviations and Conversion Factors}

\begin{tabular}{|c|c|}
\hline AT-II: & Alveolar cells type II \\
\hline BPD: & Bronchopulmonary dysplasia \\
\hline $\mathrm{D}:$ & Dexamethasone \\
\hline E2: & $17 \beta$-Estradiol, $\mathrm{pg} / \mathrm{mL} \times 3.671=\mathrm{pmol} / \mathrm{L}$ \\
\hline ER- $\alpha$ : & Estrogen receptor alpha \\
\hline ER- $\beta$ : & Estrogen receptor beta \\
\hline ICI: & $\begin{array}{l}\text { ICI } 182.780=7 \alpha \text { - }[9-[(4,4,5,5,5- \\
\text { Pentafluoropentyl }) \text { sulphinyl }] \text { nonyl }] \\
\text {-estra-1,3,5(10)-triene-3,17 } \beta \text {-diol }\end{array}$ \\
\hline M: & Molar \\
\hline MEM: & Minimum essential medium \\
\hline Mrna: & Messenger ribonucleic acid \\
\hline P: & Progesterone, $\mathrm{ng} / \mathrm{mL} \times 3.18=\mathrm{nmol} / \mathrm{l}$ \\
\hline PR: & Progesterone receptor \\
\hline RDS: & Respiratory distress syndrome \\
\hline RU 486: & Mifepristone \\
\hline SP-B: & Surfactant protein B \\
\hline SP-C: & Surfactant protein $\mathrm{C}$ \\
\hline VEGF: & Vascular endothelial growth factor A \\
\hline
\end{tabular}

\section{Acknowledgment}

The first and the second authors contributed equally to this manuscript.

\section{References}

[1] A. N. Husain, N. H. Siddiqui, and J. T. Stocker, "Pathology of arrested acinar development in postsurfactant bronchopulmonary dysplasia," Human Pathology, vol. 29, no. 7, pp. 710717, 1998.

[2] A. J. Jobe, "The new BPD: an arrest of lung development," Pediatric Research, vol. 46, no. 6, pp. 641-643, 1999.

[3] P. Hercz, "Quantitative changes in steroid and peptide hormones in the maternal-fetoplacental system between the 28th40th weeks of pregnancy," Acta Medica Hungarica, vol. 42, no. 1-2, pp. 29-39, 1985.

[4] T. M. Siler-Khodr, "Endocrine and paracrine function of the human placenta," in Fetal and Neonatal Physiology, R. A. Polin and W. W. Fox, Eds., vol. 1, pp. 74-85, WB Saunders, Philadelphia, Pa, USA, 1992.

[5] A. Trotter, L. Maier, H.-J. Grill, T. Kohn, M. Heckmann, and F. Pohlandt, "Effects of postnatal estradiol and progesterone replacement in extremely preterm infants," The Journal of Clinical Endocrinology \& Metabolism, vol. 84, no. 12, pp. 45314535, 1999. 
[6] A. Trotter, L. Maier, T. Kohn, W. Böhm, and F. Pohlandt, "Growth of the uterus and mammary glands and vaginal cytologic features in extremely premature infants with postnatal replacement of estradiol and progesterone," American Journal of Obstetrics and Gynecology, vol. 186, no. 2, pp. 184-188, 2002.

[7] A. Trotter, L. Maier, M. Kron, and F. Pohlandt, "Effect of oestradiol and progesterone replacement on bronchopulmonary dysplasia in extremely preterm infants," Archives of Disease in Childhood: Fetal and Neonatal Edition, vol. 92, no. 2, pp. F94-F98, 2007.

[8] C. Beyer, E. Küppers, M. Karolczak, and A. Trotter, "Ontogenetic expression of estrogen and progesterone receptors in the mouse lung," Biology of the Neonate, vol. 84, no. 1, pp. 59-63, 2003.

[9] S. S. Khosla, G. J. W. Smith, P. A. Parks, and S. A. Rooney, "Effects of estrogen on fetal rabbit lung maturation: morphological and biochemical studies," Pediatric Research, vol. 15, no. 9, pp. 1274-1281, 1981.

[10] A. Thuresson-Klein, A. H. Moawad, and P. Hedqvist, "Estrogen stimulates formation of lamellar bodies and release of surfactant in the rat fetal lung," American Journal of Obstetrics and Gynecology, vol. 151, no. 4, pp. 506-514, 1985.

[11] A. J. Chu and S. A. Rooney, "Estrogen stimulation of surfactant synthesis," Pediatric Pulmonology, vol. 1, supplement 3, pp. S110-S114, 1985.

[12] S. S. Khosla and S. A. Rooney, "Stimulation of the fetal lung surfactant production by administration of $17 \beta$-estradiol to the maternal rabbit," American Journal of Obstetrics and Gynecology, vol. 133, no. 2, pp. 213-216, 1979.

[13] A. Trotter, M. Ebsen, E. Kiossis, et al., "Prenatal estrogen and progesterone deprivation impairs alveolar formation and fluid clearance in newborn piglets," Pediatric Research, vol. 60, no. 1, pp. 60-64, 2006.

[14] N. Ferrara, "Vascular endothelial growth factor: basic science and clinical progress," Endocrine Reviews, vol. 25, no. 4, pp. 581-611, 2004.

[15] P. Carmeliet, V. Ferreira, G. Breier, et al., "Abnormal blood vessel development and lethality in embryos lacking a single VEGF allele," Nature, vol. 380, no. 6573, pp. 435-439, 1996.

[16] C. Galambos, Y.-S. Ng, A. Ali, et al., "Defective pulmonary development in the absence of heparin-binding vascular endothelial growth factor isoforms," American Journal of Respiratory Cell and Molecular Biology, vol. 27, no. 2, pp. 194203, 2002.

[17] V. Compernolle, K. Brusselmans, T. Acker, et al., "Loss of HIF- $2 \alpha$ and inhibition of VEGF impair fetal lung maturation, whereas treatment with VEGF prevents fatal respiratory distress in premature mice," Nature Medicine, vol. 8, no. 7, pp. 702-710, 2002.

[18] C.-M. Chen and L.-F. Wang, "High-dose vascular endothelial growth factor increases surfactant protein gene expressions in preterm rat lung," Early Human Development, vol. 83, no. 9, pp. 581-584, 2007.

[19] M. P. Applanat, H. Buteau-Lozano, M. A. Herve, and A. Corpet, "Vascular endothelial growth factor is a target gene for estrogen receptor and contributes to breast cancer progression," Advances in Experimental Medicine and Biology, vol. 617, pp. 437-444, 2008.

[20] M. D. Mueller, J.-L. Vigne, E. A. Pritts, V. Chao, E. Dreher, and R. N. Taylor, "Progestins activate vascular endothelial growth factor gene transcription in endometrial adenocarcinoma cells," Fertility and Sterility, vol. 79, no. 2, pp. 386-392, 2003.
[21] M. D. Mueller, J.-L. Vigne, A. Minchenko, D. I. Lebovic, D. C. Leitman, and R. N. Taylor, "Regulation of vascular endothelial growth factor (VEGF) gene transcription by estrogen receptors $\alpha$ and $\beta$," Proceedings of the National Academy of Sciences of the United States of America, vol. 97, no. 20, pp. 10972-10977, 2000.

[22] H. M. Fraser, H. Wilson, A. Silvestri, K. D. Morris, and S. J. Wiegand, "The role of vascular endothelial growth factor and estradiol in the regulation of endometrial angiogenesis and cell proliferation in the marmoset," Endocrinology, vol. 149, no. 9, pp. 4413-4420, 2008.

[23] E. Küppers, A. Krust, P. Chambon, and C. Beyer, "Functional alterations of the nigrostriatal dopamine system in estrogen receptor- $\alpha$ knockout (ERKO) mice," Psychoneuroendocrinology, vol. 33, no. 6, pp. 832-838, 2008.

[24] M. Kipp, A. Norkute, S. Johann, et al., "Brain-region-specific astroglial responses in vitro after LPS exposure," Journal of Molecular Neuroscience, vol. 35, no. 2, pp. 235-243, 2008.

[25] B. Thébaud and S. H. Abman, "Bronchopulmonary dysplasia: where have all the vessels gone? Roles of angiogenic growth factors in chronic lung disease," American Journal of Respiratory and Critical Care Medicine, vol. 175, no. 10, pp. 978-985, 2007.

[26] K. R. S. Brown, K. M. England, K. L. Goss, J. M. Snyder, and M. J. Acarregui, "VEGF induces airway epithelial cell proliferation in human fetal lung in vitro," American Journal of Physiology, vol. 281, no. 4, pp. L1001-L1010, 2001.

[27] T. D. Le Cras, N. E. Markham, R. M. Tuder, N. F. Voelkel, and S. H. Abman, "Treatment of newborn rats with a VEGF receptor inhibitor causes pulmonary hypertension and abnormal lung structure," American Journal of Physiology, vol. 283, no. 3, pp. L555-L562, 2002.

[28] I. H. Connelly, G. L. Hammond, P. G. R. Harding, and F. Possmayer, "Levels of surfactant-associated protein messenger ribonucleic acids in rabbit lung during perinatal development and after hormonal treatment," Endocrinology, vol. 129, no. 5, pp. 2583-2591, 1991.

[29] N. Sweezey, S. Tchepichev, S. Gagnon, K. Fertuck, and H. O'Brodovich, "Female gender hormones regulate mRNA levels and function of the rat lung epithelial $\mathrm{Na}$ channel," American Journal of Physiology, vol. 274, no. 2, pp. C379-C386, 1998.

[30] P. Acs, M. Kipp, A. Norkute, et al., " $17 \beta$-estradiol and progesterone prevent cuprizone provoked demyelination of corpus callosum in male mice," Glia. In press.

[31] K.-M. Lau, S. C. Mok, and S. M. Ho, "Expression of human estrogen receptor- $\alpha$ and $-\beta$, progesterone receptor, and androgen receptor mRNA in normal and malignant ovarian epithelial cells," Proceedings of the National Academy of Sciences of the United States of America, vol. 96, no. 10, pp. 5722-5727, 1999.

[32] T. A. H. Jarvinen, M. Pelto-Huikko, K. Holli, and J. Isola, "Estrogen receptor $\beta$ is coexpressed with $\mathrm{ER} \alpha$ and PR and associated with nodal status, grade, and proliferation rate in breast cancer," American Journal of Pathology, vol. 156, no. 1, pp. 29-35, 2000.

[33] A. C. B. Cato and H. Ponta, "Different regions of the estrogen receptor are required for synergistic action with the glucocorticoid and progesterone receptors," Molecular and Cellular Biology, vol. 9, no. 12, pp. 5324-5330, 1989.

[34] D. X. Wen, Y.-F. Xu, D. E. Mais, M. E. Goldman, and D. P. McDonnell, "The A and B isoforms of the human progesterone receptor operate through distinct signaling pathways within target cells," Molecular and Cellular Biology, vol. 14, no. 12 , pp. 8356-8364, 1994. 
[35] C. Ballaré, M. Uhrig, T. Bechtold, et al., "Two domains of the progesterone receptor interact with the estrogen receptor and are required for progesterone activation of the c-Src/Erk pathway in mammalian cells," Molecular and Cellular Biology, vol. 23, no. 6, pp. 1994-2008, 2003.

[36] M. Nauck, M. Roth, M. Tamm, et al., "Induction of vascular endothelial growth factor by platelet-activating factor and platelet-derived growth factor is down-regulated by corticosteroids," American Journal of Respiratory Cell and Molecular Biology, vol. 16, no. 4, pp. 398-406, 1997.

[37] M. J. Acarregui, S. T. Penisten, K. L. Goss, K. Ramirez, and J. M. Snyder, "Vascular endothelial growth factor gene expression in human fetal lung in vitro," American Journal of Respiratory Cell and Molecular Biology, vol. 20, no. 1, pp. 14-23, 1999.

[38] A. J. Bhatt, S. B. Amin, P. R. Chess, R. H. Watkins, and W. M. Maniscalco, "Expression of vascular endothelial growth factor and Flk-1 in developing and glucocorticoid-treated mouse lung," Pediatric Research, vol. 47, no. 5, pp. 606-613, 2000.

[39] C. T. D’Angio, W. M. Maniscalco, R. M. Ryan, N. E. Avissar, K. Basavegowda, and R. A. Sinkin, "Vascular endothelial growth factor in pulmonary lavage fluid from premature infants: effects of age and postnatal dexamethasone," Biology of the Neonate, vol. 76, no. 5, pp. 266-273, 1999.

[40] R. Bossé, R. Rivest, and T. Di Paolo, "Ovariectomy and estradiol treatment affect the dopamine transporter and its gene expression in the rat brain," Molecular Brain Research, vol. 46, no. 1-2, pp. 343-346, 1997.

[41] C. S. Watson, R. A. Alyea, B. E. Hawkins, M. L. Thomas, K. A. Cunningham, and A. A. Jakubas, "Estradiol effects on the dopamine transporter-protein levels, subcellular location, and function," Journal of Molecular Signaling, vol. 1, article 5, pp. 1-14, 2006.

[42] H. Mukai, T. Tsurugizawa, M. Ogiue-Ikeda, et al., "Local neurosteroid production in the hippocampus: influence on synaptic plasticity of memory," Neuroendocrinology, vol. 84, no. 4, pp. 255-263, 2007. 


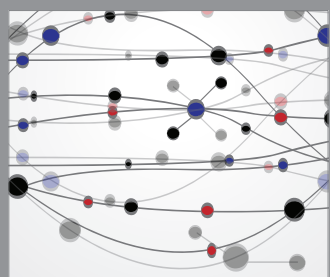

The Scientific World Journal
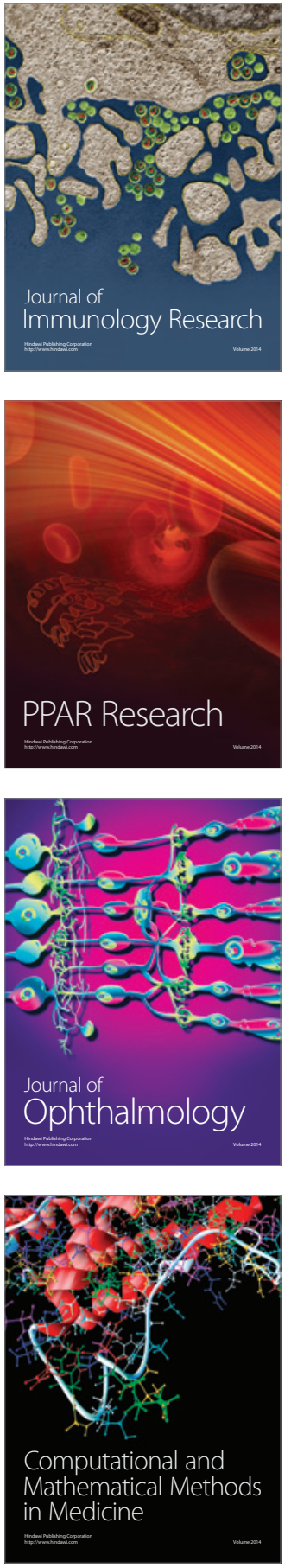

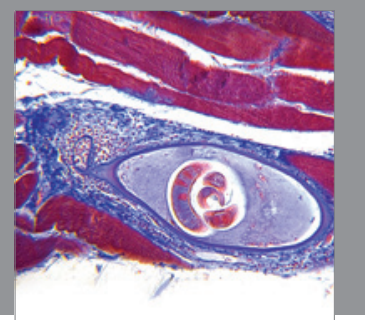

Gastroenterology

Research and Practice
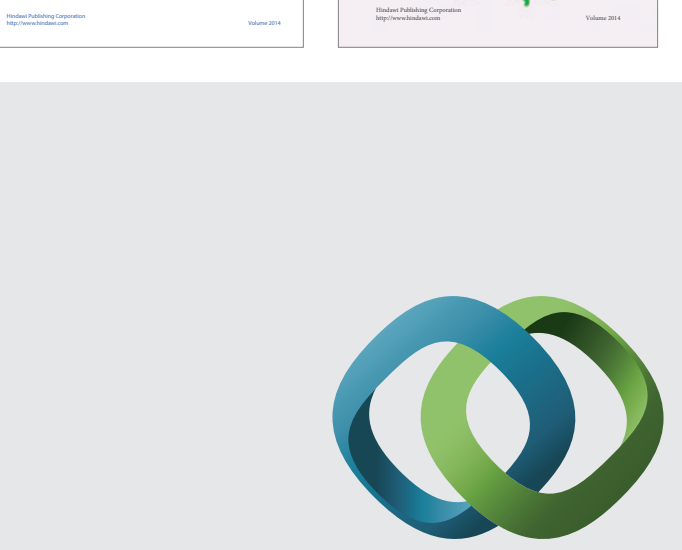

\section{Hindawi}

Submit your manuscripts at

http://www.hindawi.com
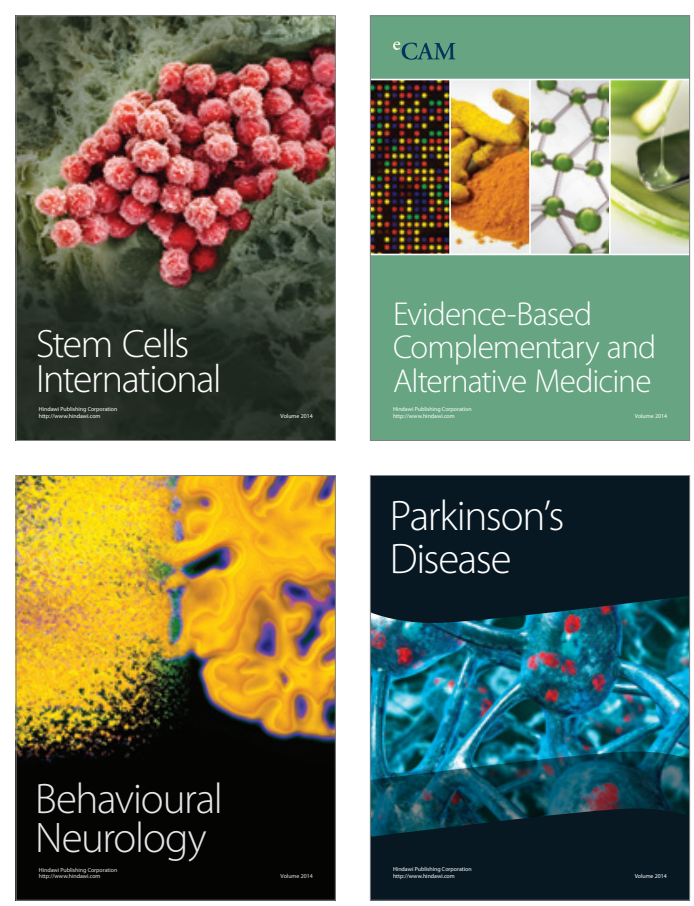

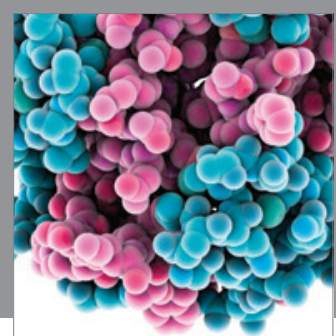

Journal of
Diabetes Research

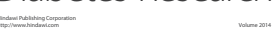

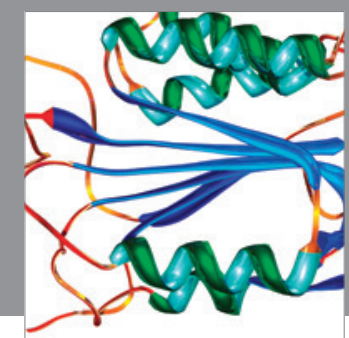

Disease Markers
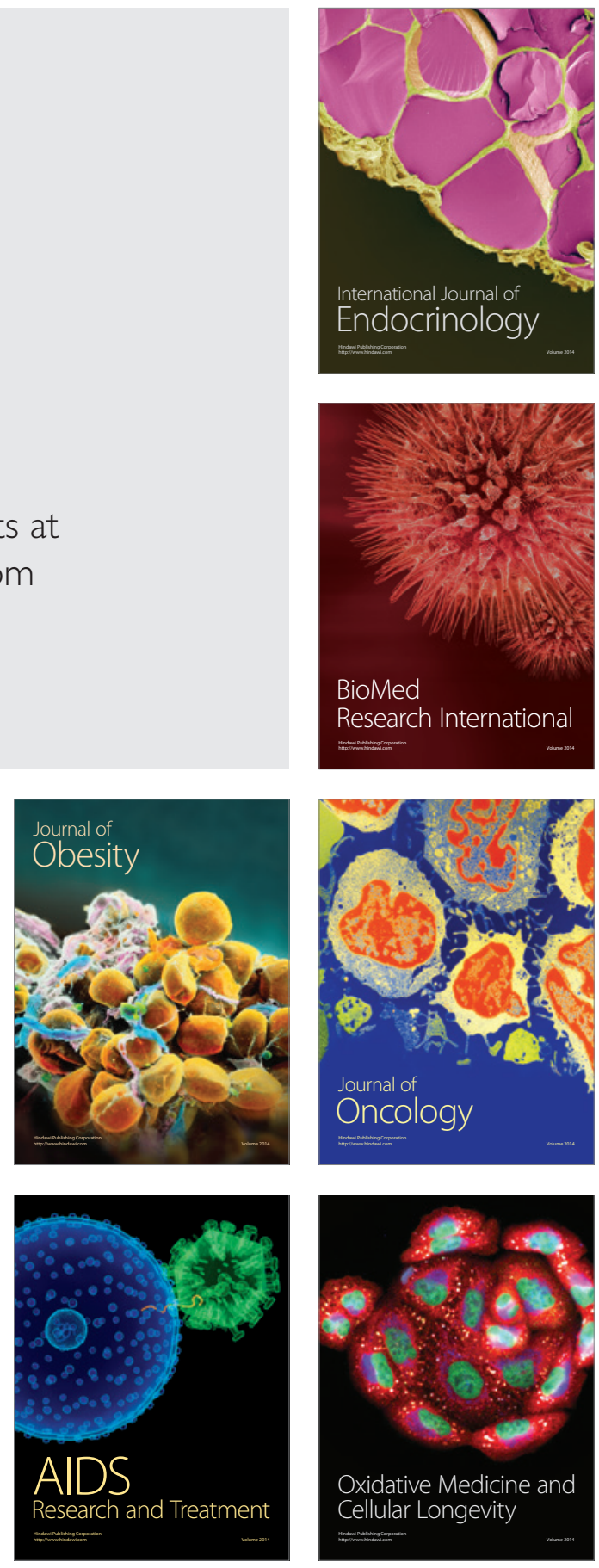